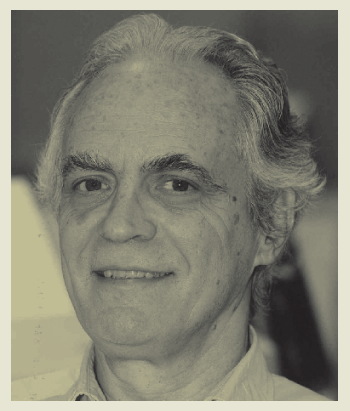

\title{
ABRINDO O CONTÊINER DE MALDADES
}

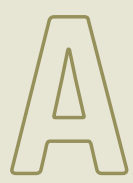

s promessas de campanha, dizia um velho político, têm validade de 100 dias, que é o intervalo entre a eleição e a posse. Entre nós, esse prazo foi reduzido a 70 . Antes que a vaca começasse a tossir, a nova equipe econômica tomou as primeiras medidas para o rearranjo das quatro taxas do apocalipse: juros, câmbio, impostos e salários. O esperanto econômico sentencia: é necessário aumentar os primeiros, desvalorizar o segundo, elevar os terceiros e comprimir os quartos. Juros e impostos já subiram. O impacto nos dois restantes é uma questão de tempo.

A lógica do ajuste é que para melhorar (uma possibilidade) é preciso piorar (uma certeza). Em economias de mercado, o investimento depende do setor privado e, para isso, é indispensável que os empresários, sem os quais a economia não cresce, recobrem a confiança na política econômica após quatro anos de malabarismos. Foram muitos - entre tantos, uma contabilidade destrutiva - que nos levaram ao atoleiro da estagnação. A inflação crescerá num primeiro momento, e o mesmo acontece com o desemprego, os salários deixarão de aumentar e poderão até cair. Os juros em alta contribuirão para um câmbio valorizado, é verdade, mas se eles subirem também nos Estados Unidos este efeito poderá ser mais do que neutralizado. As perspectivas para 2015 são ruins.

O que faria a oposição, caso tivesse vencido as eleições? Nada muito diferente. Talvez adotasse medidas desagradáveis mais rapidamente a fim de colher frutos na segunda metade do mandato. Para a presidente Dilma, no entanto, eleições deixaram de ser um problema. Agora é problema do PT.
No interior deste partido, as tensões aumentam e as primeiras rachaduras começam a aflorar. Dizem alguns, com razão, que a presidente está fazendo exatamente o que criticava em seus oponentes. E a resposta de Dilma parece ser o silêncio: deixa que seus eloquentes e obedientes ministros se queimem e ouçam o ranger de dentes da militância e do povo. O da Fazenda parece contar com o apoio dos empresários, mas isso só não basta: é preciso saber quanto tempo levará até que esse apoio se transforme em investimentos privados, mesmo porque os do governo devem minguar em função do ajuste fiscal.

Além disso, como diria aquele célebre filósofo alemão do século 19 que não frequentava barbeiros: "O espectro do apagão ronda a economia brasileira!". Em 2001, ele causou um recuo de 1,5 pontos percentuais do PIB. Neste ano, em que as estimativas de crescimento já são próximas de zero, se faltar energia certamente teremos um crescimento negativo do PIB. E como desgraça pouca é bobagem, enfrentamos também a ameaça de falta d'água. Nos principais conglomerados urbanos do país - São Paulo, Rio de Janeiro e Belo Horizonte -, os reservatórios estão baixos mesmo no fim da estação chuvosa. As famílias já enfrentam sérios problemas de abastecimento.

A maior parte de nossos recursos hídricos é consumida pela indústria e pela agricultura. $\mathrm{E}$ a água está escassa exatamente no sudeste, onde esse consumo é maior. O ano de 2015 será marcado como o do pior dos mundos: recessão, inflação e desemprego, combinados com falta d'água e de energia elétrica. 